\title{
Torpedo maculopathy with an anisometropic amblyopia in a 5-year-old Caucasian girl: case report
}

\author{
Maculopatia torpedo numa criança caucasiana de 5 anos de idade com ambliopia anisometrópica: \\ relato de caso
}

Marco Dutra-Medeiros ${ }^{1}$, Paula leitão ${ }^{1}$, Ana Magriço $^{1}$, Alcina Toscano $^{1}$

\begin{abstract}
The aim of this study is to report a clinical case of asymptomatic female Caucasian children with torpedo maculopathy. A 5-year-old girl was referred to our clinic for routine evaluation. The ophthalmic examination revealed best-corrected visua acuity of 20/20 in both eyes, without any changes in the biomicroscopy. Fundus examination showed normal findings in one eye, whereas in the contralateral eye it disclosed, in the temporal sector of the macular region, a whitish, atrophic, oval chorioretinal lesion with clearly defined margins. Posterior evaluations documented the stability of the lesion. Torpedo maculopathy diagnosis is based on its characteristic shape and peculiar location. The differential diagnosis has to be estabilished versus choroidal lesions (melanoma and nevus), congenital or iatrogenic hyperplasia of the retinal pigment epithelium (RPE) and particularly versus the congenital pigmented lesions associated with Gardner's syndrome.
\end{abstract}

Keywords: Pigment epithelium of eye/pathology; Retinal diseases/congenital; Macula lutea; Visual acuity; Eye neoplasms/pathology; Humans; Female; Child; Case report

\begin{abstract}
RESUMO
Os autores descrevem um caso clínico de uma criança caucasiana, 5 anos do sexo feminino, com maculopatia torpedo. Ao exame oftalmológico apresentava uma acuidade visual corrigida de 10/10 e sem alterações à biomicroscopia. À fundoscopia apresentava uma lesão oval isolada, esbranquiçada, atrófica, unilateral, de margens bem definidas no setor temporal da região macular. Avaliações posteriores documentaram a estabilidade da lesão. O diagnóstico da maculopatia torpedo baseia- se na sua forma característica e localização peculiar. É importante o diagnóstico diferencial com lesões da coroideia (melanoma e nevo), hiperplasias congênitas ou iatrogênicas do epitélio pigmentado da retina (EPR) e com lesões congênitas associadas à síndrome de Gardner.
\end{abstract}

Descritores: Epitélio pigmentado ocular/patologia; Doenças retinianas/congênito; Macula lutea; Acuidade visual; Neoplasias oculares/patologia; Humanos; Feminino; Criança; Relato de caso

\section{INTRODUCTION}

Torpedo maculopathy is a single hypopigmented congenital nevi of the retinal pigment epithelium (RPE), first described by Roseman, Gass $^{(1)}$, in 1992. Gass described it as a focal congenital abnormality of the RPE consisting in an asymptomatic oval lesion located along the horizontal raphe, in the temporal portion of the macular region.

Subsequently, Daily ${ }^{(2)}$ described an oval albinotic lesion in the temporal macula that was asymptomatic and consistent with one of the solitary focal developmental anomalies of the REP described by Roseman, Gass. While the lesions described by Daily were albinotic in appearance (paramacular albinotic spot syndrome), other authors have observed lesions with varying degrees of pigmentation.

It would therefore seem that torpedo maculopathy is the appropriate name for this condition, since it specifically describes the lesion shape wich include variations in pigment.

\section{CASE REPORT}

A 5 -year-old Caucasian girl was referred for routine examination. Medical history was unremarkable.

On examination, the uncorrected visual acuity was 20/200 in the right eye and 20/80 in the left eye. Pupils were equal, round, and reactive to light with no afferent pupillary defect. Slit-lamp biomi- croscopy revealed no abnormalities of the anterior segment. Under cycloplegia, her best corrected visual acuity was: OD 20/80 with +2.75 $+2.00 \times 100$ and OS 20/20 with +1.00+0.75 x 100 .

Dilated fundus examination revealed a sharply demarcated oval chorioretinal lesion OD, located $<1$ DD (disc diameter) temporal to the macula, with a characteristic torpedo-like shape with the tip pointig towards the macula. The lesion was whitish, atrophic and approximately 1 DD in width and 0.5 DD in height. On binocular stereo fundoscopy, both retinal and choroidal vessels were unobscured except in a small pigment clump located within the temporal border of the lesion (Figure 1). The peripheral retina was normal and devoid of any chorioretinal lesions bilaterally. The retinal examination of the left eye was unremarkable (Figure 2).

The refractive error was corrected and the patient begun an occlusion therapy of the right eye.

Because the lesion had remained stable over the past 4 years and clinically was consistent with a torpedo maculopathy lesion, no fluorescein was ordered. Currently, she has a BVCA of 20/20 in both eyes for near and distance vision. Retina assessments were performed on a regular basis, every six months, by performing fundoscopy and proceeding to its documentation by retinography. The absence of symptoms and the normal findings obtained in the various investigations performed suggest the benign nature of the lesion.

Submitted for publication: July 18, 2012

Accepted for publication: June 20, 2013

Study carried out at Department of Ophthalmology, Central Hospital of Lisbon Center, Lisbon, Portugal.

Physician, Department of Ophthalmology, Central Hospital of Lisbon Center, Lisbon, Portugal.

Funding: No specific financial support was available for this study

Disclosure of potential conflicts of interest: M.Dutra-Medeiros, None; P.Leitão, None; A.Magriço, None; A.Toscano, None.

Correspondence address: Marco Dutra Medeiros. Centro Hospitalar de Lisboa Central. Rua António José Serrano, 1150-199 - Lisboa - Portugal - E-mail: marcodutramedeiros@gmail.com 


\section{DISCUSSION}

Torpedo maculopathy is a congenital lesion of the RPE characterized by a very unique shape and location. There are few cases described in the literature, making it difficult to assess the prevalence. Classification with various nomenclatures may add to the scarcity of reports (Table 1), further complicating the issue of prevalence.

Roseman, Gass described a case of a 12-year-old male with normal visual acuity and no abnormalities on Amsler grid or Goldmann visual field testing ${ }^{(1)}$. The authors observed a solitary oval lesion, located temporal to the macula in the left eye, with a wedge shaped tail that obscured choroidal layers. They hypothesized that this"hypopigmented nevus of the RPE" was composed of intact RPE cells containing a milky white material of abnormal melanin or its precursor. Daily ${ }^{(2)}$ described a collection of oval albinotic lesions located temporal to the macula centered on the horizontal raphe with a tail pointing toward the macula. He referred to this as "paramacular albinotic spot syndrome". Some authors ${ }^{(3)}$ observed the same type of lesion and called it "torpedo maculopathy" based on its pathognomonic shape. Other authors ${ }^{(4)}$ observed three cases of asymptomatic unilateral lesions in a child and two adults. A- and B-scan ultrasonography did not detect any retinochoroidal defects or calcifications in the macular area. Shields et al. ${ }^{(5)}$, reported two cases of torpedo maculopathy. Based on observations from Streeten ${ }^{(6)}$, they speculate that torpedo maculopathy could represent a persistent defect in the development of the RPE in the fetal temporal bulge. Accordingly, the uniform location and size of this lesion points toward a congenital defect during RPE embryogenesis as well as its fetal development. So far, the largest case series has been published by Golchet et al. ${ }^{(7)}$, in 2009, and inclu-

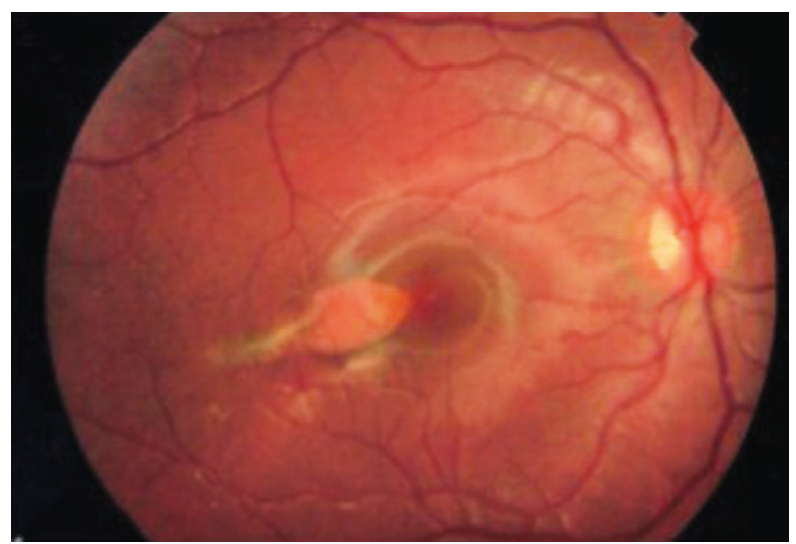

Figure 1. Fundus photo OD - Torpedo-like shape lesion, in the temporal sector of macular region. ded the medical records of 13 patients sharing similar features after evaluation by fluorescein angiography, autofluorescence and optical coherence tomography (OCT).

The differential diagnosis must include choroidal lesions (melanoma and nevus), congenital anomalies of the RPE and focal retinal pigmentation due external agents (traumatic or drug-induced toxic effects) $)^{(4-8)}$

Beyond torpedo maculopathy, there are several other congenital lesions of the RPE, including combined hamartoma of the retina and RPE, congenital simple hamartoma of the RPE and particularly the congenital hypertrophy of the RPE (CHRPE) linked to Gardner's syndrome, a dominantly inherited familial cancer syndrome that includes familial adenomatous polyposis and various soft tissue tumours. Those lesions associated with Gardner's syndrome tend to be bilateral, with multiple solitary lesions that are located away from the macula, much smaller and more irregular in shape ${ }^{(8)}$.

Acquired focal retinal pigmentation (due trauma, drugs, inflammation) presents a highly irregular shape, with erratic distribution of pigment and is often accompanied by signs suggesting the nature of the lesion.

In our clinical case the characteristic shape and the location in the temporal macula suggested the diagnosis. Of note is the fact that our patient had a hyperopic astigmatism. Despite being interesting, it cannot be concluded that refractive error is related to torpedo maculopathy. To the best of our knowledge this association has already been described in the literature by Pian et al. ${ }^{(9)}$. Beyond this, no studies link refractive error to this lesion.

Performing retinography is a good means of monitoring the nevus. Fluorescein angiography, ultrasonography, and macular

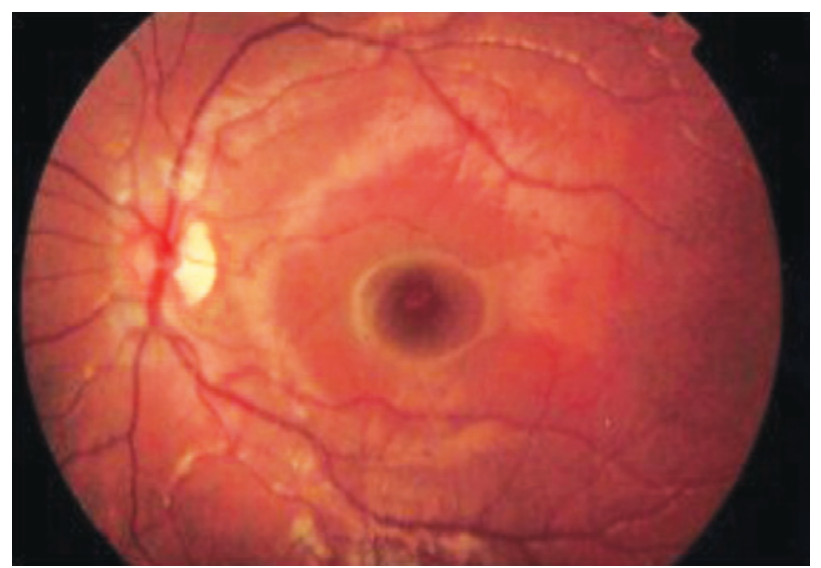

Figure 2. Fundus photo OS - normal.

Table 1. Literature review of torpedo maculopathy

\begin{tabular}{lll}
\hline Author & \multicolumn{1}{c}{ Name used in publication } & Hypothesis of origin \\
\hline Roseman, Gass ${ }^{(1)}$ & Hypopigmented nevus of the RPE & Abnormal melanin deposition in intact RPE cells \\
Daily ${ }^{(2)}$ & Paramacular albinotic spot syndrome & None given \\
Teitelbaum et al. ${ }^{(3)}$ & Torpedo maculopathy & Prenatal disturbance in choroidal vasculature to macular area \\
Rigotti et al. ${ }^{(4)}$ & Torpedo maculopathy & Congenital hypertrophy of the RPE \\
Shields et al. ${ }^{(5)}$ & Torpedo maculopathy & Persistent defect in the development of the RPE in the fetal temporal bulge \\
Golchet et al. ${ }^{(7)}$ & Torpedo maculopathy & Disfunction or absence of RPE \\
Mahieu, Mathis ${ }^{(10)}$ & Maculopathie en torpille & None given \\
Sharma et al. ${ }^{(1)}$ & Macular coloboma & Maldevelopment of the retina \\
Townsed et al. ${ }^{(12)}$ & Paramacular coloboma & Embryological lesions occurring along the horizontal raphe \\
\hline
\end{tabular}

$\mathrm{RPE}=$ retinal pigment apithelium. 
threshold perimetry should be considered if there is a change in the size or shape of the lesion or if a change in vision is documented by the patient or examiner ${ }^{(7-10)}$. Due benign nature, this pathology has a good prognosis. In the absence of ocular symptoms, annual evaluations of the nevus are sufficient.

\section{REFERENCES}

1. Roseman RL, Gass JD. Hypopigmented nevus of the retinal pigment epithelium in the macula. Arch Ophthalmol. 1992;110(10):1358-9. Erratum in: Arch Ophthalmol. 1992; 110(12):1762.

2. Daily MJ. Torpedo maculopathy or paramacular spot syndrome. In: New Dimensions in Retina Symposium. 1993; Nov. 10-13.Chicago.

3. Teitelbaum BA, Hachey DL, Messner LV. Torpedo maculopathy. J Am Optom Assoc 1997:68(6): 373-6.

4. Rigotti M, Babighian S, Carcereri de Prati, Marchini G. Three cases of a rare congenital abnormality of the retinal pigment epithelium: torpedo maculopathy. Ophthalmologica. 2002;216(3):226-7.

5. Shields CL, Guzman JM, Shapiro MJ, Fogel LE, Shields JA. Torpedo maculopathy at the site of the fetal "bulge". Arch Ophthalmol. 2010;128(4):499-501.

6. Streeten BW. Development of the human retinal pigment epithelium and the posterior segment. Arch Ophthalmol. 1969;81(3):383-94

7. Golchet PR, Jampol LM, Mathura JR Jr, Daily MJ. Torpedo maculopathy. Br J Ophthalmol. 2010;94(3):302-6.

8. Shields JA, Shields CL. Tumours and related lesions of the pigment epithelium. In: Shields JA, Shields CL., eds. Intraocular tumours: an atlas and textbook. $2^{\text {nd }}$ ed. Philadelphia, PA: Lippincott Williams \& Wilkins; 2008. p.431-80.

9. Pian D, Ferruci S, Anderson SF, Wu C. Paramacular coloboma. Optom Vis Sci. 2003; 80(8):556-63.

10. Mahieu L, Mathis A. [«Torpedo » maculopathy]. J Fr Ophtalmol 2003:26(5):533. French.

11. Sharma S, Naqvi A, Cruess AF. Bilateral macular colobomata. Can J Ophthalmol. 1996; $31(1): 27-8$.

12. Townsed J, Selvin G, Grifin J, Comer G. Visual fields: clinical case presentations. Stoneham: Butterworth-Heinmann, 1991. 